thanking him for the kindness and hospitality of his servants and country, and the next morning took train for Brod and thence by the Orient Express to Paris. The President of our Society is sending a special letter of thanks to over fifty of those who did so much for our comfort, and our particular gratitude is due to the Director of the Archaeological Museum at Zagreb, M. Hoffiller, and to his indefatigable wife, both of whom accompanied us from Zagreb onwards through Yugoslavia. The arrangements of the Yugoslavia Express Agency, who organized the whole expedition, were in every respect perfect.

\title{
Obituary Notice
}

Rodolfo Lanciani. The death of Professor Rodolfo Amedeo Lanciani on May 20 of the present year removes from our midst one of the two men (the other being Professor Christian Huelsen, whose 7oth birthday was celebrated last November) who have done more than any one else to promote the study of the topography of the city of Rome since it became the capital of Italy in 1870 . At that time Lanciani, a young man of twenty-four, was just at the beginning of his archaeological career : and in $187 \mathrm{I}$ he became secretary of the newly formed municipal archaeological commission, and remained a member of it until his death. In the same year he was elected an honorary Fellow of our Society. He was also elected Hon. Corresponding Member of the Royal Institute of British Architects in 1894, being Gold Medallist in 1900; and he received honorary degrees from Oxford, Aberdeen, Glasgow, and other universities. In 1877 he published his first report in the Notizie degli Scavi as director of excavations for the city of Rome, and in 1878 he became professor of Roman topography in the University, and held the chair until 1927. The rapid growth of the city in the 'seventies' and ' eighties' kept him continually occupied, but he found time to publish excellent reports promptly: and many of the articles that he wrote in regard to excavations still in progress are of permanent value as contributions to our knowledge of the subject, while the total mass of his literary production is very considerable. ${ }^{\mathrm{I}}$ His knowledge of the monuments of Rome and of their history was astonishing, as those who heard his lectures at the University of Rome will remember: but he understood how to convey it to the general public in a pleasant and acceptable form, as is shown by the fact that he delivered three courses of lectures at different times in England and in the United States, and that he was frequently invited to lecture in Rome before the British and American Archaeological Society; while generations of visitors to Rome owe a debt of gratitude to him for acting as their guide, philosopher, and friend. During their visit to Rome their Majesties King George

I A full bibliography will be found at the end of the memoir which I have written for the Archivio della Societa Romana di Storia Patria for 1928. 
and Queen Mary were shown the sights of Rome by him, and the K.C.V.O. which was afterwards conferred on him was a well-merited recognition of his services. His knowledge of English also enabled him to bring out in that language a number of volumes dealing with ancient, medieval, and Renaissance Rome, written in a pleasant and attractive anecdotical style, while containing an enormous amount of items of outof-the-way information from published and unpublished sources-a remark which is applicable with especial force to the illustrations. His monumental plan of Rome on the scale of 1:1000 (Forma Urbis), his work on the aqueducts, his Ruins and Excavations of Ancient Rome, and his Storia degli Scavi (which unluckily only goes as far as the end of the sixteenth century) are all of them of permanent value to the specialist: while the Museum of the Roman Empire, which grew out of the archaeological exhibition of its various provinces in 19 I I, and the Antiquarium Comunale on the Caelian-a museum of Roman construction and decoration-both owe their origin to him. The work that he did in the study of the Roman Compagna, on the other hand, has remained in great part unpublished : a scheme for the preparation of a map of it never came into being, and how much time he devoted to it is known only to a few, and among them myself. For it is to him that I owe my first introduction to the delights of this fascinating region, and my initiation into the exploration of its ancient remains; and I remember well, and with how much truth, he would remind us that we were the last who would see it as it was in that desolation, so dear to the artist and the archaeologist, though naturally, and rightly, abhorred by the social reformer. Indeed, what I, like many others, owe to him is not to be expressed in words; to students he was kindness itself, and always ready to give of his time and trouble. The splendid library which he had formed included a large amount of manuscript material as yet unpublished, including notes that he had not been able to work up, as well as an important collection of books, prints, and drawings; and it has fortunately been secured in its entirety to Rome.

Thomas AshbY. 